\title{
A TUTELA REPRESSIVA QUANTO AO TRABALHO ESCRAVO CONTEMPORÂNEO: DIÁLOGOS ENTRE DIREITO PENAL E TRABALHISTA E A (IMPOSSÍVEL) SEPARAÇÃO ENTRE LIBERDADE E DIGNIDADE HUMANA
}

\author{
THE REPRESSIVE LEGAL PROTECTION AGAINST MODERN SLAVERY: \\ REASONINGS BETWEEN CRIMINAL AND LABOR LAW, AND THE (IMPOSSIBLE) \\ DIVISION BETWEEN FREEDOM AND HUMAN DIGNITY
}

Renato de Almeida Oliveira Muçouçah ${ }^{1}$

\begin{abstract}
RESUMO: O artigo tem como escopo analisar o trabalho escravo contemporâneo e verificar se ele é produto novo da História ou resquício dos arcaicos modelos produtivos existentes até aproximadamente o início do século XX, que ressurgiu com força na década de 1970. Fez-se necessário refletir sobre como reprimir esse delito verificando-se qual a tutela mais eficaz para tanto. Buscou-se, por meio da análise dedutiva de bibliografia especializada, além de sucinta apreciação indutiva de julgados, testar dedutivamente hipóteses pelas quais se pudessem dar respostas eficazes à repressão do trabalho escravo e à proteção de direitos fundamentais dos trabalhadores. A tutela trabalhista, ainda que se valha de conceito oriundo do direito penal, dialoga também com outras fontes (Convenções Internacionais, por exemplo): trabalho escravo não é apenas privação de liberdade, mas também de dignidade da pessoa humana. Os estudos trabalhistas apresentam-se mais permeáveis a esse conceito e permitem não apenas a repressão ao trabalho escravo em sentido estrito, mas também a outras formas indignas de trabalho: comportam até mesmo a responsabilidade civil preventiva. Desta forma, a Ação Civil Pública trabalhista resulta como o meio mais eficaz para reprimir o trabalho escravo, sobretudo por meio de condenação por danos morais no sistema dos punitive damages.
\end{abstract}

PALAVRAS-CHAVE: Trabalho escravo; trabalho degradante; punitive damages; dano moral coletivo; responsabilidade civil preventiva.

\begin{abstract}
The article aims to analyze the modern slavery and check if it is a new question of History or remnant of the archaic existing production models until approximately the beginning of the twentieth century, who resurfaced with force in the 1970s. It was necessary to reflect on how to suppress this crime verifying what is the most effective protection for such. It sought, through deductive analysis of relevant literature, apart from brief inductive appreciation judged, deductively test hypotheses by which it could respond effectively to the repression of slave labor and the protection of fundamental rights of workers. The labor protection, even though it uses arising concept of criminal law also dialogues with other sources (international conventions, for example): slave labor is not only deprivation of liberty,

\footnotetext{
${ }^{1}$ Professor Adjunto II dos cursos de Graduação e Mestrado em Direito da Faculdade de Direito da Universidade Federal de Uberlândia-MG (UFU). Professor colaborador do curso de Mestrado em Direito da Universidade Federal do Maranhão (UFMA). Possui graduação em Direito pela Universidade Estadual Paulista Júlio de Mesquita Filho (UNESP), Mestrado e Doutorado em Direito do Trabalho pela Faculdade de Direito da Universidade de São Paulo (USP) e Pós-Doutorado em Direito pela Universidade Federal do Maranhão.e-mail: renato.mucoucah@terra.com.br

- $\quad$ Artigo recebido em 22/02/2016 e aprovado para publicação em 09/12/2017
} 
but also of human dignity. The Labour Law studies seem more permeable to this concept and allow not only the repression of slavery in the strict sense, but also to other degrading forms of work: behave even preventive civil liability. Thus, the labor Public Civil Action appears as the most effective means to crack down on slavery, especially through condemnation for pain and suffering in the punitive damages system.

KEYWORDS: Slavery; degrading work; punitive damages; collective pain and suffering; preventive civil liability.

\section{Introdução}

Quase toda a História do Brasil se entrelaça umbilicalmente com o regime de produção escravocrata, baseando sua economia eminentemente agrária com a força de trabalho oriunda de pessoas escravizadas. Embora, de início, a colonização portuguesa tenha tentado escravizar os nativos (indígenas), apenas o tráfico de pessoas negras oriundas da África e trazidas ao Brasil para venda e compra resolveu a questão desse modelo produtivo arcaico em termos de capitalismo.

O modelo exposto demonstra um estágio de capitalismo arcaico porque regimes baseados em escravidão, servidão ou outras formas de anulação da liberdade do trabalhador é a antítese do próprio capitalismo. Tal sistema econômico somente poderá existir se houver uma massa de consumidores que permita a existência do mercado, de maneira a circular riqueza nos mais variados setores. Ora, em um sistema escravagista não há massa alguma de consumidores, já que não há dinheiro pago a quem vive de seu trabalho. Em se tratando de trabalho escravo haverá apenas pequenos grupos de latifundiários que, valendo-se desse labor sem remuneração, iniciam uma espécie de acumulação primitiva do capital, parecida com aquela verificada nos primórdios da Revolução Industrial.

O combate ao trabalho em condições análogas à de escravo, portanto, dá-se mais em razão da própria lógica econômica do mercado do que por uma luta pela afirmação de direitos humanos. Um bom exemplo é a igualdade perante a lei e a possibilidade de contratação entre particulares. A igualdade entre contratantes, ainda que meramente no plano formal, não deixou de ser uma conquista, pois somente seres livres poderiam estabelecer relações uns com os outros. O contrato - e nesse caso se insere também o contrato de trabalho - é instrumento pelo qual, num primeiro momento, se fabrica, produz e reproduz riquezas, alimentando 
continuamente o sistema capitalista. Em momentos posteriores da história, porém, ele não apenas foi insuficiente para eliminar desigualdades no plano material entre os contratantes, como permitiu concentração de capital a quem detinha os meios de produção.

No plano internacional já existem diversas normativas a respeito, sobretudo Convenções da Organização Internacional do Trabalho. No Brasil o trabalho escravo é considerado crime, e se encontra tipificado no próprio Código Penal, em seu artigo 149. A exegese penalista permite concluir que apenas as formas ali descritas constituem-se em trabalho escravo, gênero de outras espécies como trabalho forçado e, em alguns casos, o trabalho degradante. Por essa razão, buscou-se fornecer elementos conceituais para separar a figura do trabalho em condições análogas à de escravo em relação às situações que lhe possam ser aparentemente semelhantes. A crítica ao conceito, muitas vezes considerado vago e impreciso, deve ser analisada não apenas objetivamente, mas também sob outra pergunta: afinal, a quem interessa restringir o conceito de trabalho escravo?

No mais, por ser tema cujo estudo demanda conhecimentos de mais de uma seara jurídica, o tratamento dedutivo da pesquisa bibliográfica, que analisará obras acerca do tema proposto, também contará com breve análise indutiva de posições já demonstradas pelo Supremo Tribunal Federal; ademais, busca-se a análise de dois julgados (um do Tribunal Regional do Trabalho da $16^{\mathrm{a}}$ Região e outro do Tribunal Regional do Trabalho da $1^{\mathrm{a}}$ Região) acerca de assuntos relacionados ao tema exposto, de maneira a apresentar respostas quanto às lacunas encontradas em teste dedutivo de hipóteses (método hipotético-dedutivo).

Por fim, haverá a consulta ao ordenamento jurídico positivo, baseando-se o trabalho na análise sistemática da legislação existente e de Projetos de Lei em tramitação no Poder Legislativo.

\section{O trabalho escravo em nova roupagem}

Conforme François Ewald, o direito em si não continha uma "essência" no século XIX: tratava-se de uma categoria de pensamento que descrevia certas práticas contratuais as quais se refletiam na sociedade; eram práticas normativas, racionais, mas práticas também de coerção e sanção social (EWALD, 1986, p. 30). No sistema capitalista buscou-se ampliar cada 
vez mais o conceito de trabalhador, a fim de que certas proteções sociais não atingissem apenas os trabalhadores subordinados (empregados).

De acordo com Robert Castel, ao longo das transformações do modo de produção capitalista os trabalhadores vivenciaram algumas formas de integração, dentre elas a condição proletária e a condição operária. Hoje, vive-se na sociedade salarial: praticamente todos os seres humanos vivem de algum tipo de remuneração, seja oriunda do trabalho subordinado, do autônomo ou de novas formas de conquista de dinheiro por meio do labor humano. Na primeira fase da integração, havia quase que a exclusão dos proletários do corpo social: sujeitos de direitos, considerados formalmente iguais aos seus contratantes, suas questões como a própria nomenclatura escolhida sugere - resolviam-se com base no contrato. $\mathrm{O}$ proletário não existe para a sociedade porque apenas produz para ela; é tão miserável que não consegue sequer consumir o que produziu. Sem qualquer força política ou construção de identidade com aqueles que vivem em condições semelhantes às suas, o homem, nesta fase, trabalha apenas para reproduzir-se materialmente (CASTEL, 1998, p. 415-436).

A posterior passagem à condição operária traduziu-se na integração por outra maneira: a percepção da lógica subordinante, que foi a alavanca do mundo do trabalho no fito de constituir uma espécie de coesão social, com a qual se forjou uma identidade de classe (ROMAGNOLI, 2001, p. 9-10). Aliás, é nesta fase que surge o direito do trabalho e o salário deixa de ser a mera retribuição pontual pelas tarefas desempenhadas, nos dizeres de Castel (1998, p. 416). Ele passa a ser mais: garante direitos, permite o acesso a direitos sociais como aposentadoria, auxílio por enfermidade relacionada ou não ao trabalho, assim como possibilita à classe trabalhadora conquistar o consumo, a instrução, o lazer e a propriedade.

Embora se cuide no trabalho apenas da análise brasileira dos processos de produção, estes se repetiram com maior ou menor intensidade em diversos países do globo: seria equivocado afirmar, portanto, a visão eurocêntrica do trabalho acima exposta como espécie de verdade dos fatos existentes na produção econômica brasileira. Ademais, registre-se certa tendência nas ciências sociais em geral em estabelecer comparações evolutivas entre as sociedades: estas se dão com base na visão dos dominantes (sociedade colonizadora), em detrimento da visão dos dominados, de maneira a estabelecer comparações falseadas, as quais só poderiam favorecer as verdades reveladas pela metrópole (SANTOS, 2014, p. 59-61). 
Não sem motivos, portanto, é impossível estabelecer uma leitura linear do trabalho no Brasil, como se a escravidão se desse por finda, de forma peremptória, pela abolição paulatina que se tentava promover e se tornou absoluta (em termos formais) com a promulgação da Lei 3.353, de 13 de maio de 1888 (Lei Áurea). Mesmo cursos de Direito do Trabalho bastante conceituados apenas fazem menção à existência do trabalho escravo no Brasil: preocupam-se apenas em estabelecer as bases que deram origem ao direito do trabalho. Afirma-se, de forma linear, que a Lei Áurea suprimiu formas de trabalho incompatíveis com a dinâmica jurídicotrabalhista e, a partir de então, lançaram-se bases para algum tipo de codificação do trabalho livre (DELGADO, 2015, p. 110-112).

A afirmação não pode ser considerada válida caso se deseje indagar a transição do trabalho escravo para o livre. É válida, porém, a observação de Manuel Alonso Olea: o direito do trabalho se forma a partir da existência de sujeitos livres e capazes, mas não se nega, em absoluto, que ainda exista o trabalho forçado, tal como já existiu na Antiguidade ou no medievo (escravidão, servidão, etc.). Por isso, o trabalho forçado é uma prática antijurídica, não sendo tratado como direito, e sim - o que é correto - grave violação do sistema jurídico-normativo (ALONSO OLEA, 2009, p. 78-79).

O trabalho escravo coexistiu com o trabalho livre por um considerável espaço de tempo. A economia brasileira centrava-se no garimpo de pedras preciosas, na indústria açucareira e um tanto na pecuária, mas havia uma população livre de aproximadamente dois milhões de pessoas, número idêntico ao de escravos no ano de 1850. Perceba-se, pois, que desde o início da colonização do Brasil até o ano de 1850 (quando a colônia já era independente), o número estimado de escravos trazidos da África nesses trezentos e cinquenta anos havia sido de 15 milhões (SALADINI, 2012, p. 94). Logo, haver uma população de dois milhões de escravos no Brasil em pleno ano de 1850, já no Segundo Império, é dado importante a ser considerado.

A mão-de-obra livre no Brasil em pleno século XIX assumiu importância tal que ganhou regulamentação em diversas normas: houve leis que regulamentavam o contrato de locação de serviços de forma esmiuçada e severa nos anos de 1830, 1837 e 1879. Passou-se também a prever contratos de parceria e de meação, afinal, somente grandes latifundiários possuíam condições de adquirir e manter escravos. 
Nas palavras de Sidnei Machado, o conjunto de leis da primeira metade do século XIX destinou-se a regulamentar contratos de prestação de serviço, de parceria ou de meação entre nacionais e também entre brasileiros e estrangeiros; já por meio do Decreto 2.820, de 22 de março de 1879, a legislação era muito mais ampla e minuciosa: além de regulamentar o trabalho livre dos imigrantes e dos nacionais, continha disposições obrigando homens livres e libertos ao trabalho, além de disciplinar toda a execução contratual (proibindo manifestações grevistas, por exemplo). Essas formas de trabalho representaram a mudança de paradigma por que passava a sociedade brasileira oitocentista: havendo assalariados livres, tais trabalhadores se tornariam consumidores; os proprietários dos meios de produção, por sua vez, acumulavam riqueza, mas também consumiam produtos outros. O trabalho escravo, embora filho do capitalismo, foi excluído pela família em razão de sua intrínseca indignidade: os trabalhadores escravizados nada recebiam e, por isso, não podem consumir nem gerar riquezas ou trocas, que são imprescindíveis à existência do capital (MACHADO, 2003, p. 151-158).

Todavia, como bem explica José de Souza Martins, essa "terceira escravidão" hoje existente no Brasil possui ainda laços com o capitalismo, embora possa parecer paradoxal a afirmação. O mundo moderno se fundou na extrema acumulação primitiva de capital, quando nada era ou deveria ser repartido: o sistema escravagista é próprio dessa fase primária do capitalismo e, portanto, teve grande importância no curso da História. Já no atual estágio da humanidade, em que o capital assenta suas bases no sistema financeiro e na especulação, só se pode conceber o trabalho como livre, igualitário e contratual, sem relações de sujeição. O neoescravismo, portanto, não é uma continuidade do sistema escravocrata existente no Brasil de séculos atrás, mas é a reprodução pontual de aspectos ainda primários na exploração da força de trabalho (MARTINS, 2014, p. 203-204).

A história do capitalismo, assim como a história do homem, das religiões ou do direito não existe sem descontinuidades. Um discurso supostamente histórico-evolutivo pode até mesmo ser traçado, mas não sem a devida ressalva de que sistemas mais primitivos coexistem com aqueles considerados modernos. Walter Benjamin, por exemplo, chega a considerar o capitalismo mais que um sistema econômico: ele possui todos os requisitos de uma religião, e talvez mais dogmática que qualquer outra. Não possui nenhuma teologia moral que não seja o utilitarismo puro e simples: é a expressão "religiosa" que mais se dedica ao culto, muito mais 
que qualquer outra expressão cultural ou religiosa existente no curso da História (BENJAMIN, 2013, p. 21-22).

A questão a ser posta, porém, é a da continuidade e também da descontinuidade discursiva. Por grande espaço de tempo a História passou a ser lida como uma sucessão de fenômenos que se sobrepõem sobre outros mais antigos; a descontinuidade em algum desses fatores era suprimida, pois não revelava a ideologia das ações humanas num dado espaço: tratavam-se, pois, de exceções à regra. Talvez seja muito difícil falar historicamente no trabalho em condições análogas à de escravo em pleno século XXI, porque essa forma de acumulação do capital é primitiva e já foi superada por diversas outras.

Em verdade, conforme Michel Foucault, essa descontinuidade (in casu, das formas de trabalho no sistema capitalista) acaba por confirmar a existência não de uma, mas de várias ideologias em determinado espaço temporal. Não se deve suprimir algo que já foi historicamente superado por sucessivos processos, os quais se supõem serem mais afeitos à modernidade (superação do sistema feudal, por exemplo), mas analisar qual a razão de existirem tais descontinuidades no sistema posto e buscar a explicação para a sua persistência (FOUCAULT, 2008, p. 10-11).

Na atualidade o trabalho exercido em condições análogas à de escravo é combatido em toda a ordem internacional: não apenas na Convenção sobre a Escravidão, da Sociedade das Nações, em 1926, como também na Convenção 29 da Organização Internacional do Trabalho (OIT), braço da Organização das Nações Unidas (ONU), a qual expressamente determina que os países do mundo devem suprimir o trabalho forçado em quaisquer de suas formas: a Convenção é de 1930, e mais de vinte anos depois ganhou reforço com outra Convenção, de número 105 (SERVAIS, 2010, p. 294). O combate ao trabalho forçado em quaisquer de suas formas é, a propósito, uma das principais preocupações da OIT.

Ainda assim, no plano internacional, é possível verificar a persistência do trabalho em condições análogas à de escravo. No Sudão foi possível observar - ainda na década de 1990 a preservação de formas exploratórias como aquelas tradicionais, existentes no Brasil (formalmente) até 1888. A Mauritânia traz um retrato ainda pior: embora a escravidão tenha sido formalmente abolida apenas no ano de 1981, cerca de 90.000 (noventa mil) pessoas ainda tinham "proprietários" (RASSAM, 1999, p. 321-322). Ademais, algo que tem contribuído para a persistência do trabalho forçado é a migração: somente em se tratando da Europa, 
estima-se que a exploração do trabalho dos imigrantes ilegais, ainda em 2002, rendeu $€$ 12.000.000,00 (doze milhões de euros). Pessoas são escravizadas por se encontrarem ilegalmente em determinado país (PLANT, 2004, p. 66-67).

Por tratar-se de um modus operandi promovido quase que por completo à margem da lei, não há estatísticas seguras acerca do trabalho forçado no Brasil a partir de 1888. José de Souza Martins, um dos maiores expoentes do Brasil acerca do tema, relata que desde 1877 fluxos migratórios oriundos em grande parte do Ceará dirigiam-se à Amazônia para participar do então incipiente ciclo da borracha. Lá se desenvolveu o regime da escravidão por dívida, à revelia de toda legislação brasileira, mas a própria crise de 1910 pôs fim a essa exploração.

O sistema da peonagem (ou escravidão por dívida) ganhou notável força no Brasil durante as décadas de 1970 e de 1980, graças a uma política específica do regime ditatorial de então: buscou-se, por meio de incentivos fiscais e renúncias tributárias do governo, promover a exploração da Amazônia legal. Dificilmente a mão-de-obra dos grandes centros se deslocaria a uma região do país em que tudo haveria de ser desbravado por baixos salários. Passou-se a aliciar trabalhadores de algumas regiões do país, com a promessa de ganhos futuros. Estima-se que, nesse período, ao menos 200 (duzentos) mil peões foram escravizados na derrubada das matas e formação de fazendas na região norte do país. Houve, já à época, uma série de denúncias da CONTAG (Confederação Nacional dos Trabalhadores na Agricultura), da Comissão Pastoral da Terra e até mesmo da Polícia Federal acerca do tema.

A Polícia Federal, diga-se de passagem, acabou por investigar o caso em razão do tráfico interno de pessoas no território brasileiro. Ao menos até 2002, 75\% dos casos ocorreram na chamada Amazônia legal (Estados de Mato Grosso, Pará e Rondônia). O sistema era sempre o mesmo: após a força de trabalho ser recrutada, o trabalhador chegava a um local distante de sua terra já se descobrindo devedor do transporte e da alimentação durante a viagem. Os alimentos no local de trabalho eram vendidos pelo empregador a preços abusivos e, por ganharem muito pouco, os trabalhadores não conseguiam pagar a dívida contraída. Ostensivamente eram vigiados, sob ameaça de morte, para que não tentassem fugir rumo à sua terra natal, que era em regra o interior dos Estados do Piauí e do Maranhão, onde era escassa a possibilidade de conseguir emprego (MARTINS, 2014, p. 206-209).

Os processos históricos possuem descontinuidades discursivas, e a neoescravidão é uma delas: repelida pela legislação do planeta, e por interesses ditados pelo próprio capital, é 
ainda utilizada por razões as mais diversas: aproveita-se da condição de debilidade de determinado grupo de pessoas (marginalizados pela fome, imigrantes ilegais, etc.) e, mediante falsa promessa de trabalho digno (o que constituiu engodo), certos grupos tentam por meio do trabalho forçado estabelecer seu comércio para obter lucratividade acima do esperado.

A área da Amazônia legal faz um bom exemplo: por ser a região ainda rústica e bastante desabitada, abrir fronteiras exige força de trabalho em grande massa; a escassez de gente para trabalhar nesse tipo de serviço deveria impulsionar os produtores - até mesmo pelo conceito capitalista da questão - a buscar mão de obra oferecendo valores elevados. A solução mais simples é a ilegal: o aliciamento de trabalhadores pobres e a escravidão por dívidas, que permitirá a acumulação capitalista primária.

\section{O conceito jurídico de trabalho escravo: à guisa de algumas proposições}

Na seara de proposição para um conceito jurídico do trabalho dito escravo, há alguns termos que são recorrentes. Os principais são: trabalho decente, trabalho degradante, trabalho forçado e, por fim, trabalho em condições análogas à de escravo. Como todos convergem ora mais, ora menos ao intuito da proteção de direitos sociais mínimos do trabalhador, é mister defini-los, até mesmo para que bem se delimite o objeto do presente estudo. Tais conceitos encontram-se, de forma esparsa e não sistematizada, confundidos no discurso jurídico e, portanto, é necessário aclará-los ainda que minimamente.

Para José Cláudio Monteiro de Brito Filho, o trabalho decente é aquele que respeita garantias mínimas conferidas ao trabalhador, sendo que tais garantias se encontram, no mais das vezes, positivadas como direitos fundamentais na ordem constitucional dos países do globo. O citado autor elenca requisitos previstos em documentos jurídicos internacionais, destacando que a pessoa deverá ter liberdade para escolher o mister que pretende labutar, assim como igualdade de oportunidades para trabalhar: nesse caso, não poderá haver discriminações de qualquer natureza, sejam elas fundadas em dogmas religiosos, questões de gênero, orientação sexual, etnia, cor da pele ou procedência (BRITO FILHO, 2013, p. 49).

O trabalho decente é aquele que garante qualidade de vida a quem labora, pois qualquer pessoa deve ter o direito de exercer seus misteres com segurança e salubridade. 
Ainda em relação à qualidade de vida no trabalho, é necessário garantir condições justas de trabalho, máxime no respeito às jornadas de prestação de serviço e aos períodos de repouso.

Trabalho decente, por fim, é aquele que garante remuneração adequada à complexidade do labor exercido e, para tanto, reconhece a liberdade sindical em todas as suas dimensões (BRITO FILHO, 2013, p. 49-54), tal como a Constituição Federal estabelece em seus artigos $4^{\circ}$ a 11 (CONSTITUIÇÃO, 2016). Platon Teixeira de Azevedo Neto corrobora em integralidade a presença necessária de todos os requisitos acima citados como verdadeira "fórmula" para aquilatar-se determinado trabalho como decente ou não (AZEVEDO NETO, 2015, p. 118-119).

É preciso analisar minuciosamente o que cada nomenclatura pretende significar, vez que a hermenêutica, ao menos nesse caso, nem sempre é clara. $\mathrm{O}$ trabalho degradante parece ser a absoluta e clara antítese do que seria o trabalho decente. Nesse aspecto, o estudo de Wilson Ramos Filho fornece a exata medida do que se pretende afirmar: condições degradantes de trabalho ou trabalho executado em condições degradantes não se confundem com o conceito de trabalho degradante, só por si. "Enquanto as condições degradantes de trabalho são absolutamente incompatíveis não apenas com a proteção nacional, mas também com os ditames expressos no Direito Internacional do Trabalho", o trabalho degradante é reconhecido pela legislação trabalhista. "O trabalho em condições degradantes se definiria pela relação entre o trabalhador e os meios de prestação do trabalho; o trabalho degradante pelo tipo de atividade realizada" (RAMOS FILHO, 2008, p. 97).

Há certa tendência de monetarização de riscos (e, por via de consequência, de direitos) no Brasil. Determinados trabalhos são aceitos e tolerados pela ordem jurídica desde que se pague ao trabalhador o adicional de periculosidade e/ou de insalubridade, por meio dos quais o trabalho degradante transmuta-se em decente. As condições (e não as atividades) degradantes intoleráveis seriam aquelas, pois, em que a legislação do trabalho não permite a “compra”, via pagamento de adicionais, pelo sacrifício ou pelo risco da vida do empregado na atividade desenvolvida pelo empregador (RAMOS FILHO, 2008, p. 99-100).

Termo também bastante utilizado pela doutrina é o trabalho forçado, expressão que ficou consagrada no direito internacional do trabalho (e, em especial relevo, pelas Convenções 29 e 105 da OIT). Em síntese, o trabalho forçado é aquele exercido de forma não voluntária, mediante ameaça de alguém quanto a uma penalidade qualquer. Apenas pela 
definição já se nota, pois, que trabalho forçado não é sinônimo de trabalho degradante: no primeiro há ausência de consentimento e o trabalho ser exercido mediante engodo, ameaça ou violência, seja esta de qual natureza for.

De acordo com a conceituação de trabalho degradante, percebe-se que não há similaridade entre os casos: é possível que haja trabalho degradante sempre que a atividade for insalubre ou perigosa, mesmo com o empregador pagando pelo adicional de periculosidade ou insalubridade. Isso não torna o trabalho, de per si, ilícito. Já as condições degradantes de trabalho existem em diversos tipos de trabalho, seja ele urbano ou rural: basta que se negue ao trabalhador um ou vários de seus direitos fundamentais existentes no curso da relação de emprego, ao passo que o trabalho forçado parece ligar-se muito mais ao direito à liberdade de locomoção que a outras restrições (ABRAMO; MACHADO, 2011, p. 61).

A forma mais elementar de trabalho forçado é a escravidão pura e simples, e o sequestro de pessoas para trabalharem obrigatoriamente em favor de outrem: casos dessa natureza foram relatados não apenas em alguns países da África, mas também no Brasil. A mais comum maneira de trabalho forçado continua a ser a chamada escravidão por dívidas, quando existe a figura de um aliciador (no caso brasileiro, chamado de "gato") que patrocina viagem e alimentação até o local de trabalho, prometendo salários e condições dignas de trabalho.

Quando a pessoa chega ao local já se descobre devedora, e é proibida de abandonar o trabalho antes que a dívida seja quitada; no mais das vezes, essa dívida nunca termina, pois o trabalhador é cobrado em preços abusivos por moradia e alimentação, de maneira a sempre ser devedor. Tais dívidas não conseguem ser adimplidas, já que o trabalhador não é remunerado de maneira suficiente para quitar com essas dívidas abusivas. Em todos esses casos, assim como nos demais que serão relatados, existe a ameaça, que pode ser física ou psíquica, e direcionada à pessoa do trabalhador ou alguém que lhe é próximo.

Outros modelos de trabalho escravo também chamam a atenção: em algumas regiões, sobretudo naquelas em que ainda há dificuldade de comunicação, por um lado, e ausência de mão-de-obra, por outro, há práticas coercitivas de contratação. O Judiciário e o sindicato dos trabalhadores, nesses locais, não existem ou são estruturas frágeis. Também trabalhadores doméstico podem encontrar-se com frequência em situações de trabalho forçado, já que suas atividades são desenvolvidas no âmbito residencial do empregador: muitas crianças são 
cedidas por seus pais para serem exploradas em uma residência, ou são filhos de empregados que - à maneira dos "livres" escravos nascidos após a Lei do Ventre Livre, no Brasil trabalham com seus pais e são impedidos, de alguma forma, de procurar novos horizontes ou outros empregos.

Por fim, o tráfico de pessoas, seja interno ou externo, tem contribuído cada vez mais para uma espécie de "globalização escravista": pessoas de países pobres mudam-se para terras que supostamente lhes darão melhores condições de trabalho e acabam por depararem-se com situações absolutamente diversas daquelas inicialmente descritas pelos aliciadores especializados no tráfico humano (BUSSE; BRAUN, 2003, p. 57-59).

O termo "redução [de alguém] a condição análoga à de escravo" é uma criação brasileira: trata-se do crime tipificado no artigo 149 do Código Penal, conforme redação determinada pela Lei 10.803/03, o qual tem servido como paradigma ao Judiciário brasileiro máxime à Justiça Federal e à do Trabalho - para definir o que seria a desumana superexploração do trabalho.

\section{O conceito jurídico-penal brasileiro de trabalho escravo: breves considerações}

Consoante pôde-se notar ao longo das assertivas acima lançadas, o trabalho em condições análogas à de escravo é previsão lançada pela redação do artigo 149 do Código Penal: consuma-se, pois, quando o trabalhador é submetido a trabalho forçado, jornada extenuante e condições degradantes de trabalho. Popularizou-se, porém, nomenclatura mais simples (embora tecnicamente incorreta): trabalho escravo.

A expressão trabalho forçado é a mais consagrada na atualidade, quando se exige que determinada pessoa preste serviços (mesmo contra sua vontade), sob ameaça de qualquer natureza. Por fim, o trabalho degradante é aquele executado em condições inadequadas, sem observância de normas de segurança, medicina e saúde do trabalho (FRANCO FILHO, 2014, p. 47). Todas as nomenclaturas acima declinadas, em que pesem as diferenças guardadas entre si, são comumente confundidas. É mister, portanto, separá-las. Inicialmente, há que salientar o que todas práticas têm em comum: são reprimidas pela legislação trabalhista, constitucional 
(especialmente artigo 243 do texto magno) e, em não raras ocasiões, pelo próprio ordenamento jurídico-penal.

O Código Penal de 1940 já previa em sua redação original o delito constante de seu artigo 149, mas o fazia de forma extremamente sucinta e, portanto, prenhe de dúvidas interpretativas: "reduzir alguém a condição análoga à de escravo". Ora, e em que consistiria tal redução? Na coisificação da pessoa, como no período da escravidão negra no Brasil? Para muitos, o crime apenas se consumava quando havia anulação total e completa da liberdade humana (MATTJE, 2006, p. 27). A Lei 10.803, de 11 de dezembro de 2003, alterou profundamente esse conceito, ampliando-o a uma série de situações outras ${ }^{2}$.

Há quem veja, na unicamente brasileira concepção de trabalho análogo à condição de escravo, uma espécie de gênero: nele se incluiriam espécies como o trabalho forçado e o degradante, pois são ambos atentatórios à dignidade da pessoa humana e representam o núcleo central dos direitos fundamentais do ser humano (GARCIA, 2012, p. 95).

Em que pesem abalizadas posições como a ora citada, é forçoso reconhecer, conforme dito, que nem todo trabalho degradante é, de per si, escravo: o conceito de trabalho degradante é amplo, mas sempre se refere à natureza da atividade exercida; o artigo 149 do Código Penal refere-se a condições degradante de trabalho, ou seja, meios de execução de qualquer trabalho que atentem contra a saúde e a vida do trabalhador. Logo, o trabalho degradante não se faz presente na questão do "trabalho escravo".

A tipificação do crime baseou-se, ao menos em sede primeira, no conceito de analogia: por óbvio, uma relação ou um fato só poderão ser análogos se forem comparados a outro. A referência da legislação de 1940 tinha em mente, de maneira muito provável, a semelhança - ou o conceito análogo - ao da escravidão abolida em 1888. Seria preciso verificar, pois, se a vítima recebia tratamento semelhante àquele destinado ao escravo negro

\footnotetext{
2 [...]Redução a condição análoga à de escravo

Art. 149. Reduzir alguém a condição análoga à de escravo, quer submetendo-o a trabalhos forçados ou a jornada exaustiva, quer sujeitando-o a condições degradantes de trabalho, quer restringindo, por qualquer meio, sua locomoção em razão de dívida contraída com o empregador ou preposto

Pena - reclusão, de dois a oito anos, e multa, além da pena correspondente à violência

$\S 1$ 을 mesmas penas incorre quem:

I - cerceia o uso de qualquer meio de transporte por parte do trabalhador, com o fim de retê-lo no local de trabalho;

II - mantém vigilância ostensiva no local de trabalho ou se apodera de documentos ou objetos pessoais do trabalhador, com o fim de retê-lo no local de trabalho [...] (BRASIL, 2016).
} 
nos séculos XIX e anteriores. Em síntese, a pessoa deveria ser tratada como propriedade de outrem, e por isso a atenção maior sempre se voltou à privação da liberdade e estado de sujeição (HADDAD, 2013, p. 53-54).

O tipo penal ora vigente é amplo e comporta uma variedade de situações consideradas como trabalho escravo. Inicialmente, em que pese o nomen juris do delito permanecer como "reduzir alguém a condição análoga à de escravo", a novel redação não se restringiu às situações em que ocorra restrição ou privação da liberdade (cerceamento do direito de ir e vir do trabalhador), mas também a submissão a trabalhos forçados, jornada exaustiva e/ou condições degradantes de trabalho. No entanto, como adiante se demonstrará, a fixação no conceito de restrição ou privação da liberdade acaba permeando parcela da hermenêutica existente quanto ao artigo 149 do Código Penal (já que esse artigo também serve como norte para a Justiça do Trabalho conceituar trabalho escravo).

Há ataques políticos, no cenário nacional, quanto à redação ampla do artigo 149 do digesto penal, ataques estes frequentemente utilizados pela chamada "bancada ruralista" do Congresso Nacional (Deputados e Senadores que defendem interesses de latifundiários); o ataque, todavia, também parte da Confederação Nacional da Agricultura e até mesmo, em alguns casos, por Ministros do Tribunal Superior do Trabalho (TST) e do Supremo Tribunal Federal (STF).

Existem algumas imperfeições, de fato, que podem ser apontadas: como anteriormente asseverado, o delito situa-se no Capítulo referente aos crimes contra a liberdade individual e, mais precisamente ainda, na seção que estabelece crimes contra a liberdade pessoal. Certamente com a nova redação do citado artigo, este deveria ser deslocado para os crimes contra a organização do trabalho, já que o direito penal atual não restringe o tipo penal apenas à liberdade de locomoção do trabalhador. O conceito de trabalho forçado, até mesmo por encontrar-se nas Convenções 29 e 105 da OIT, está incluído no artigo 149 do Código Penal. Aliás, o entendimento atual do Supremo Tribunal Federal a respeito do assunto é no sentido de que os direitos previstos em tais tratados teriam hierarquia superior à da legislação infraconstitucional, mas seriam inferiores à Constituição, possuindo, assim, o status sui generis de norma supralegal ${ }^{3}$. Portanto, o combate ao trabalho forçado já é uma obrigação

\footnotetext{
3 “No HC 88.240, Rel. Min. Ellen Gracie, DJ de 24-10-2008, assentou-se: 'A esses diplomas internacionais sobre direitos humanos é reservado o lugar específico no ordenamento jurídico, estando abaixo da Constituição,
} 
brasileira desde há muito, e foi reforçada no campo jurídico pela supralegalidade da Convenções 29 e 105, que cuidam esmiuçadamente sobre o assunto.

Os fenômenos relacionados à liberdade de trabalho, inclusive pessoal, ganharam guarida no digesto penal por serem atos de flagrante intencionalidade de delinquência patronal: atos como restringir a locomoção do trabalhador em razão de dívida contraída com o empregador ou seu preposto, e mesmo as formas equiparadas a trabalho em condição análoga à de escravo (cercear uso de transporte para reter o trabalhador no local de trabalho, manter vigilância ostensiva, apoderar-se de documentos ou objetos pessoais do obreiro para retê-lo no local de trabalho), demonstram a coerção individual direta exercida pelo capitalista (empregador delinquente) contra quem lhe presta serviços.

O conceito de trabalho escravo surge quando se fala em jornada exaustiva ou condições degradantes de trabalho, porque nesses casos nem sempre há a intencionalidade do empregador delinquente em coagir diretamente quem lhe presta serviços; a coerção, nesses casos, pode ser indireta. Os trabalhadores podem submeter-se a tais condições até mesmo de forma livre, quando a liberdade de contratar é utilizada pelo empregador, que não estabelece limites qualitativos à força de trabalho (FILGUEIRAS; ALVES, 2014, p. 314-317).

Certamente haveria (e há) no Congresso Nacional forças que buscassem reduzir ao máximo as possibilidades de configuração do trabalho escravo, sobretudo após a promulgação da Emenda Constitucional 81/2014 a qual, conferindo nova redação ao artigo 243 da Constituição Federal, estabeleceu que propriedades em que se localizar trabalho escravo serão expropriadas para reforma agrária ou programas de habitação popular (CONSTITUIÇÃO, 2016).

Os Tribunais têm, em grande parte, mesmo nos dias atuais, focado a existência de trabalho escravo na presença ou ausência de restrições à liberdade de locomoção na relação de emprego, desprezando outros aspectos presentes no próprio artigo 149 do Código Penal. Por outro lado, o Congresso vem apresentando Projetos de Lei que objetivam, em última análise, reduzir a abrangência do conceito de trabalho escravo, para que este não seja

porém acima da legislação interna. O status normativo supralegal dos tratados internacionais de direitos humanos subscritos pelo Brasil torna inaplicável a legislação infraconstitucional com ele conflitante, seja ela anterior ou posterior ao ato de ratificação'. No mesmo sentido, o HC 94.702, da mesma relatora e publicado na mesma data. Esses precedentes citam e seguem o HC 90.171, Rel. Min. Gilmar Mendes, DJ de 17 -8 -2007" (MENDES; BRANCO, 2014, p. 139-140). 
"subjetivamente" aferido pelo Judiciário. Na prática, a pretensão é a de limitar o trabalho escravo à questão da restrição da liberdade de locomoção.

Todas essas discussões antagônicas, contudo, têm contribuído para a baixa responsabilização da delinquência patronal no Brasil e, a depender dos argumentos utilizados, tornarão ainda menos efetivas as medidas contra o trabalho escravo, fato que constitui, sem sombra de dúvidas, retrocesso social.

\section{A atividade parlamentar em torno do trabalho em condições análogas à de escravo: entre crime e castigo (mas nem sempre com algemas)}

Na atualidade há grande variedade de Projetos de Lei tentando definir o que é trabalho escravo ou, mais precisamente, exercido em condição análoga à de escravo. Há, contudo, um Projeto principal na Câmara dos Deputados, que tramita com vários outros a ele apensados, assim como outro bastante similar tramita no Senado. O Projeto de Lei 3.824/12 pretende conceituar como trabalho escravo apenas o "serviço exigido de uma pessoa sob ameaça, coação ou violência, restringindo sua locomoção e para o qual não se tenha oferecido espontaneamente" (CÂMARA, 2016). Vê-se aqui nítida afronta à cláusula de proibição do retrocesso social pois, ao contrário do que se apregoa, a legislação brasileira já define o que é trabalho escravo, e de maneira muito mais ampla que a descrita nesse Projeto de Lei.

A bancada ruralista na Câmara dos Deputados insiste com o argumento, lançado no Projeto mencionado, que o delito tipificado no artigo 149, com suas hipóteses supostamente abertas, seria inadequado para a punição efetiva do trabalho escravo. No Senado Federal é possível encontrar o Projeto de Lei 432/13 que, ao tentar disciplinar a expropriação de locais em que se encontre trabalho escravo, delimita seu conceito quase que com as mesmas letras verificadas no Projeto de Lei existente na Câmara dos Deputados, já que os demais elementos presentes na tipificação do trabalho escravo (condições degradantes de trabalho e submissão a jornadas exaustivas) seriam de cunho subjetivo e não garantiriam segurança jurídica aos produtores rurais.

No entanto, verifica-se que a verdadeira insegurança jurídica é repassada ao polo insuficiente da relação, ou seja, aos trabalhadores, conforme artigo $2^{\circ}, \S 2^{\circ}$, do Projeto de Lei 
432/13 do Senado Federal: afirma-se que o "mero descumprimento" da legislação trabalhista não caracteriza trabalho escravo (SENADO, 2016). O Projeto encontra-se em tramitação no Senado da República, em análise na Comissão de Constituição e Justiça desde fevereiro de 2.016 .

Já que muito se fala em conceitos jurídicos indeterminados, e se eles são condenáveis sobretudo na esfera penal, consoante asseverado, o que seria "mero descumprimento" de legislação trabalhista? Ora, não há indeterminação conceitual possível. Até que ponto o descumprimento da legislação trabalhista não caracterizaria trabalho escravo ou, melhor ainda, quais os limites entre um "mero" e um "grave descumprimento" da legislação? Seria necessário imaginar a caricata figura da escravidão negra no Brasil, quando havia açoites, grilhões e ameaças para que fosse caracterizado o delito?

José Cláudio Monteiro de Brito Filho, um dos maiores estudiosos acerca do tema, assevera que o trabalho escravo é uma das espécies de violação ao gênero trabalho decente, entendido tal labor como "aquele em que são respeitados os direitos mínimos do trabalhador, necessários à preservação de sua dignidade" (2014a, p. 47). No mais, o crime tipificado no artigo 149 do Código Penal tutela não apenas a liberdade individual, mas também a dignidade humana do trabalhador. Esta é uma das razões - embora não a única, decerto - pelas quais diversos doutrinadores e aplicadores da Lei não conseguem compreender o trabalho escravo para além do cerceamento da liberdade individual: para estes, o bem jurídico-penal trata apenas de proteger a liberdade individual do trabalhador.

A tendência do STF, na leitura constitucional do trabalho escravo demonstrada no Inquérito 3.412/AL (relatado pela Ministra Rosa Weber em 2013), põe em clara evidência que há dois bens jurídicos tutelados pela norma penal: liberdade e dignidade, como já exposto (BRITO FILHO, 2014a, p. 50-51). Esse posicionamento, porém, não é pacífico sequer na Colenda Corte de Justiça do país, conforme será verificado adiante.

A jornada exaustiva, constante do já várias vezes citado artigo 149 do Código Penal, é um daqueles conceitos que, de má-fé, muitos afirmam (para querer retirá-lo da caracterização do trabalho em condições análogas à de escravo) ser excessivamente subjetiva a sua análise. O conceito, porém, é bastante claro. 
Jornada exaustiva não é a utilização da mão-de-obra em período superior àquele previsto no horário de trabalho, ainda que o trabalhador não perceba o direito ao pagamento de tais horas: para isso, uma simples Reclamação Trabalhista resolveria o problema. Por outro lado, toda pessoa não poderá exercer mais que duas horas de trabalho extraordinário por dia, como determina o artigo 59 da Consolidação das Leis do Trabalho (CLT); menores de idade estão proibidos de prestarem horas em caráter extraordinário, mas, ainda assim, e mesmo se esses descumprimentos acarretem agressões físicas e morais ao trabalhador, nem sempre se tratará de jornada exaustiva. Trabalhar, por exemplo, em 12 (doze) horas ao dia, em períodos normais, provavelmente caracterizará jornada excessiva, mas não exaustiva.

A jornada exaustiva é aquela em que, mesmo dentro de parâmetros legais, pode levar de maneira facilmente detectável e previsível - o trabalhador a ter sérios problemas de saúde, exaurindo todas as suas forças físicas e/ou psíquicas, a um ponto tal que sua própria vida é colocada em risco. Se o trabalhador for levado à exaustão, ou seja, à perda de sua força física, isso não será considerado como mera fadiga decorrente do exercício laboral: trata-se, em suma, do esgotamento completo do obreiro. Um exemplo de fácil assimilação é o corte da cana-de-açúcar: alguns trabalhadores podem ser obrigados, por exemplo, a cumprir a meta de cortar 10 (dez) toneladas de cana por dia, sob pena de não receber o salário ou percebê-lo parcialmente por não ter adimplido esta obrigação. Debaixo de Sol, sem proteção, e sendo o corte da cana realizado com a "poda" (corte por facão), esse trabalho poderá exaurir um trabalhador qualquer.

No exemplo retrocitado, não se faz nem mesmo necessário imaginar se o trabalhador é homem ou mulher, jovem ou mais idoso, se possui ou não alguma moléstia específica, etc. Qualquer ser humano comum pode, ao menos potencialmente, exaurir-se em jornada assim exigida pelas diretivas patronais (BRITO FILHO, 2014b, p. 69-73). Cada caso deve ser analisado concretamente, e isso é trabalho hermenêutico; não se trata, pois, de conceito indeterminado. Redação mais sucinta que a do artigo 121 do Código Penal (crime de homicídio) não pode existir: simplesmente fala-se em "matar alguém". O caso concreto, contudo, poderá mostrar a existência ou inexistência de agravantes, o dolo ou a culpa existente, se a pessoa agiu em legítima defesa, etc. Tudo isso, embora previsto em lei, é apreciado no caso concreto, e aí sim existem elementos extremamente subjetivos: é o caso de 
alguém matar outrem "por motivo de relevante valor social ou moral" (art. 121, $\S 1^{\circ}$ ), o que é causa para diminuição de pena). Dificilmente uma análise será mais subjetiva que essa.

No mais, a lei também fala em condições degradantes de trabalho, o que aqui não se confunde com trabalho degradante. Lívia Mendes Moreira Miraglia defende que ambos os conceitos são sinônimos, e o faz de forma muito bem fundamentada. Com a devida vênia, discorda-se apenas nesse ponto, mas a caracterização das condições degradantes de trabalho, como a autora descreve, não são de difícil aferição. Quando faltam condições mínimas de segurança e saúde do trabalho, as condições degradantes estão configuradas. Ora, que se pode dizer - até mesmo pelo senso comum - de um local de trabalho em que não haja banheiro, nem água potável para beber? Quando também não se respeita o direito ao repouso semanal e em feriados, além dos intervalos inter e intrajornada (respectivamente, onze horas de repouso entre o fim de uma jornada e o início de outra, e o intervalo para alimentação e descanso, a depender do limite diário de prestação de serviços), há prejuízo claro à saúde do trabalhador.

Como já se asseverou, o trabalho degradante pode até mesmo tornar-se tolerável pelo direito mediante certas circunstâncias: condições perigosas e/ou insalubres de trabalho, por exporem pessoas ao perigo ou ao dano à saúde, são em regra tolerados caso se pague adicional de periculosidade e/ou insalubridade ao obreiro. Em condições degradantes de trabalho isso não é possível: não se pode submeter o subordinado a alimentação de péssima qualidade ou alojamentos precários, caso isto seja necessário ao trabalho (realizado longe de grandes centros, por exemplo). Em casos dessa natureza, ou seja, quando de fato se coloca em risco potencial a integridade física e psíquica do trabalhador, e de forma tão rude que salta aos olhos a ilicitude, estar-se-á diante de trabalho em condição análoga à de escravo (MIRAGLIA, 2015, p. 142-146). Conclui-se parcialmente que, apesar da definição jurídica existente no Brasil contemplar diversas formas de trabalho em condições análogas à de escravo, há grave risco de retrocesso social vindo pelas mãos do Parlamento brasileiro, considerando-se tanto a Câmara dos Deputados quanto o Senado Federal. Esses processos, tal como alguns julgados, apenas reconhecem trabalho escravo quando há restrição da liberdade.

O próprio Supremo Tribunal Federal permanece em tal impasse: no Inquérito 2.131/DF, o Ministro Gilmar Mendes consignou de forma expressa que apenas se pode falar em trabalho escravo quando houver cerceamento da liberdade de ir e vir. As condições degradantes e as jornadas exaustivas podem, em sua compreensão, configurar trabalho 
escravo, desde que tais condições ou a jornada extenuante acabe por minar ou mitigar severamente a liberdade de ir e vir do trabalhador (BRITO FILHO, 2014b, p. 82-83).

A norma analisada é de natureza penal. À medida que o Estado organiza o monopólio da violência física, representando os interesses da burguesia, constitui-se toda a produção do discurso jurídico que recai na esfera cotidiana dos indivíduos e das coletividades. As técnicas do poder capitalista engendraram dispositivos comportamentais e micropoderes privados, tal como sói ocorrer no trabalho escravo em suas variadas formas, que se vale do modelo burguês do direito para sabotar, incredibile dictu, a própria estrutura do capital. Para que a obediência às normas existissem, foi necessário "a monopolização da violência pelo Estado, recoberta precisamente pelo deslocamento da legitimidade para a legalidade e pelo reino da lei" (POULANTZAS, 1980, p. 69).

Por esta produção eminentemente estatal da violência jurídica organizada e do discurso jurídico voltado à proteção apenas do valor legal, que não questiona a legitimidade, é que a proteção aos direitos humanos fundamentais resta fraca e não raro ineficiente, em especial quando o assunto versa sobre direitos dos trabalhadores, sejam eles de cunho social, sejam de cunho individual. Esses discursos jurídicos não existem também por mera fatalidade, pois o poder - sobretudo o econômico - busca a produção da verdade, e porque pela produção da verdade é que se produz a riqueza; todos se submetem “à verdade também no sentido em que ela é lei e produz o discurso verdadeiro que decide, transmite e reproduz, ao menos em parte, efeitos de poder" (FOUCAULT, 2005, p. 180). Portanto a lei, associada a mecanismos de poder, preenchem de verdade os discursos jurídicos que são interpretados até mesmo por quem vive a norma. Isso pode ser constatado em vários Acórdãos, mas não só.

Afinal, a quem esses discursos jurídicos servem? Foucault no mesmo texto adverte: o poder não é apenas uma dominação exercida por um indivíduo sobre outros, ou um grupo sobre outros, ou uma classe sobre outras, mas sim algo que "funciona e se exerce em rede" (2005, p. 183). A argumentação jurídica que negligencia os direitos humanos fundamentais dos trabalhadores, assim como inúmeros outros mecanismos existentes em cadeia no corpo social, constituem toda a "micro-mecânica do poder que representou um interesse para a burguesia a partir de determinado momento" (FOUCAULT, 2005, p. 185).

É este poder dos discursos jurídicos que rege comportamentos efetivos na concretude do dia-a-dia, inclusive nos ambientes de execução do trabalho, poder este que deve ser 
reinterpretado para além da ótica liberal-positivista que domina a cena jurídica há quase dois séculos. O discurso jurídico de poder, que se poderia até mesmo denominar de proteção à delinquência patronal, é reproduzido de forma acrítica por diversos Tribunais, que insistem em negar a hermenêutica escorreita da lei e buscam, de forma quase esquizofrênica, submeter conceitos como condições degradantes de trabalho, jornadas exaustivas ou trabalho forçado ao velho conceito limitador que é o da simples liberdade de ir e vir. Isso é facilmente observável em alguns Acórdãos em seguida examinados.

\section{Breve crítica ao sistema penal na repressão ao trabalho escravo}

Eugênio Raúl Zaffaroni afirma que o sistema penal possui a capacidade de criminalizar reiteradamente toda a população - uma proposição hipotética, claro - porque "o sistema penal está estruturalmente montado para que a legalidade processual não opere e, sim, para que exerça seu poder com altíssimo grau de arbitrariedade seletiva dirigida, naturalmente, aos setores vulneráveis" (1991, p. 27). O trabalho escravo existe e é sabido, mas o discurso penal não busca atingir as classes dominantes, como aqueles que produzem e reproduzem a neoescravidão, ou seja, alguns latifundiários que ainda utilizam de técnicas précapitalistas de acumulação de riquezas. Isso permite concluir, com Zaffaroni, que "os órgãos executivos têm 'espaço legal' para poder exercer poder repressivo sobre qualquer habitante, mas operam contra e quem decidem" (1991, p. 27).

É nesse exato sentido exposto por Zaffaroni que, muitas vezes, o Poder Judiciário busca restringir ao máximo os elementos possíveis para a caracterização do crime, que já está tipificado e muito bem delineado pelas normas penais. Todavia, como não é o latifundiário alguém que se pretenda deter em defesa da sociedade - ou, em outras palavras, não é contra a delinquência patronal que o discurso jurídico (sobretudo o judiciário) pretende volver suas armas. Ao contrário: é justamente para inocentar quem se vale de mão-de-obra escrava que, no mais das vezes, o direito penal se volta, retomando o conceito restrito de liberdade de ir e vir. Veja-se, nesse sentido, recente julgado do Tribunal Regional Federal da $1^{\text {a }}$ Região:

PENAL. FRUSTRAÇÃO DE DIREITO ASSEGURADO POR LEI TRABALHISTA. (ART. 203/CP). CRIMES DE REDUÇÃO DE TRABALHADOR A CONDIÇÃO ANÁLOGA À DE ESCRAV̧O (ART. 
149/CP). INEXISTÊNCIA DE PROVA DA MATERIALIDADE OU DA AUTORIA. MANUTENÇÃO DA SENTENÇA ABSOLUTÓRIA.

1. O crime descrito no art. 203 do Código Penal ocorre quando o agente frustra os direitos assegurados pela legislação trabalhista mediante o emprego de fraude ou violência. $\mathrm{Na}$ hipótese dos autos, não restou demonstrado a fraude, consistente no expediente que induz ou mantém alguém em erro.

2. Para a configuração de redução de trabalhador a condição análoga à de escravo faz-se necessária a completa sujeição da pessoa que tenha relação de trabalho ao poder do sujeito ativo do crime, não bastando a submissão do trabalhador a condições precárias de acomodações. Tal situação é censurável, mas não configura o crime do art. 149 do Código Penal.

3. Recurso desprovido 4 .

Este Acórdão, publicado no início do ano de 2016, já sintetiza muito bem a percepção de vários membros do Judiciário acerca do trabalho escravo: ele somente existirá com a completa sujeição do trabalhador a quem o contrata; ainda que existam condições degradantes (e isto é reconhecido quanto às acomodações), não se configura trabalho em condição análoga à de escravo, em afronta literal ao artigo 149 do Código Penal. A tutela criminal, embora seja absolutamente necessária nesse caso (pois o bem jurídico tutelado assim justifica), ganha baixa efetividade.

Em que pese a importância da atuação do Ministério Público do Trabalho e do Poder Judiciário Trabalhista no combate ao trabalho escravo, ainda há ranços difíceis de aceitar. $\mathrm{O}$ Tribunal Regional do Trabalho da $16^{\mathrm{a}}$ Região, responsável por conhecer e julgar ações oriundas das relações de trabalho desenvolvidas no Estado do Maranhão, propiciou um espetáculo literalmente grotesco, que conseguiu chocar todo o Brasil. Mais grave ainda: suportou a decisão em teses levantadas nesse relatório, como se passará a expor. Inicialmente, cita-se a ementa do Recurso Ordinário prolatado quanto ao Processo 01432-2009-013-16-003, oriundo da Vara do Trabalho de Açailândia-MA:

TRABALHO ANÁLOGO À CONDIÇÃO DE ESCRAVO. NÃO CONFIGURAÇÃO. DANO MORAL. EXCLUSÃO. A caracterização do trabalho escravo pressupõe a existência de meios de coação, sejam físicos, psicológicos, morais ou mesmo por dívidas, que impeçam ou dificultem o

\footnotetext{
${ }^{4}$ Apelação Criminal 0004052-21.2012.4.01.3600/MT, Rel. Pablo Zuniga Dourado. Publicado no Diário Oficial Eletrônico da Justiça Federal em 18 jan. 2016 (grifos nossos). p. 1.
} 
exercício da liberdade de ir e vir do trabalhador, situação não verificada, haja vista que o reclamante usufruiu irrestritamente do referido direito. Recurso ordinário conhecido e provido 5 .

O Relator do Acórdão não verificou restrição da liberdade de ir e vir do empregado, muito embora estivesse constatada a existência de condições degradantes de trabalho. Não houve, porém, esta simples observação no voto prevalecente do Acórdão: sustentou-se que a mesma vítima do suposto trabalho escravo já havia sido resgatada uma vez e, sponte propria, retornou ao mesmo local - anos depois - à procura de trabalho. Desta feita, chega a questionar-se: "será que o reclamante usufruía de melhores condições de moradia, alimentação e trabalho em sua cidade de origem? [...]. Custa-me crer que alguém submetido a condições degradantes [...] se dispusesse a retornar ao local”.

A tese sustentada no Acórdão pode ser facilmente questionada: por óbvio ninguém deseja submeter-se a condições degradantes de trabalho e, caso se submeta, não o faz porque as condições são iguais ou melhores que a pobreza oferece ao trabalhador. Os direitos sociais, que começaram a aflorar nas Constituições do mundo em geral na virada do século XIX para o século XX, puseram fim à concepção liberal de que o direito à vida significava uma mera abstenção: não matar. Há mais de um século, pois, já competia aos particulares e também ao Estado prover vida digna a todos, sob o primado do trabalho, por meio do qual cada um auferiria renda básica para sobrevivência. Sobreviver tornou-se muito menos um fato natural e cada vez mais um fenômeno social. Por vezes as pessoas se submetem às condições ou situações mais aviltantes possíveis de trabalho impelidas pela necessidade de sobrevivência (FERRAJOLI, 2011, p. 74-75). Em não raras ocasiões essa necessidade é ainda maior, como, por exemplo, quando se é imigrante ilegal em determinado país: apenas para sobreviver e não retornar ao país de origem, os trabalhadores podem se submeter às mais vis condições de trabalho.

Ainda que com as contradições existentes na esfera penal, em que a hermenêutica é mais direcionada à interpretação favorável ao réu, a legislação existente fornece subsídios suficientes para a propositura de um conceito eminentemente trabalhista de trabalho escravo que, sem prejuízo de sanções penais, poderá mostrar-se mais eficaz no combate à redução da

\footnotetext{
${ }^{5}$ Recurso Ordinário 01432-2009-013-16-00-3, Rel. Luiz Cosmo da Silva Júnior. Publicado no Diário Eletrônico da Justiça do Trabalho, seção Caderno Judiciário do Tribunal Regional do Trabalho, em 12 set. 2012. p. 9
} 
pessoa humana como se simples coisa fosse. A valorização da dignidade da pessoa humana pode ser tutelada por diversos meios e, certamente, aquele que se demonstrar mais apto a combater a indigitada indignidade será o meio mais apto (e, por isso, mais frequentemente utilizado) para a proteção de direitos fundamentais.

\section{Outras formas de tutela quanto ao trabalho escravo: a tutela trabalhista}

$\mathrm{Na}$ atualidade pode-se afirmar que o direito vive em constante diálogo de fontes. $\mathrm{O}$ sistema jurídico é uno, e entre as normas há hierarquia, mas as normativas em geral (oriundas da Constituição Federal, de Tratados, de Leis e até mesmo de outros diplomas normativos unilateralmente estabelecidos, como Decretos e Portarias) são os meios pelos quais se pode estabelecer uma interpretação lógica e razoável pela via dedutiva da análise de regras, ou pela via argumentativa, quando certas regras se chocarem umas com as outras acerca da tutela de determinado direito. Busca-se, pois, coerência na interpretação judicial.

As fontes do direito advindas das normas jurídicas, em sentido lato, podem estar presentes tanto no direito público ou no privado. Há um intercâmbio permanente de conceitos oriundos do direito público ou do privado para regrar situações nos mais diversos conflitos, o que demonstra a comunicabilidade existente no sistema jurídico. Em sendo as fontes normativas plurais, deve-se tentar promover o constante diálogo entre todas elas, com vistas à maior proteção possível dos direitos fundamentais (LORENZETTI, 2010, p. 81-82). O tema do presente relatório disso faz prova: o trabalho em condições análogas à de escravo, embora

seja conceito situado na esfera penal, também é referencial para a apreciação de casos concretos pela Justiça do Trabalho. As Convenções Internacionais sobre a matéria possuem status supralegal, e podem até em determinadas situações invalidar normas que lhes sejam contrárias.

Não obstante, a jurisprudência também é fonte de direito, que dialoga até mesmo com normas estatais (na questão hermenêutica) ou diante da ausência delas. Exemplo claro é o do assédio moral: embora seja um fenômeno eminentemente trabalhista (mas não apenas trabalhista), e inexista qualquer legislação federal ampla e abrangente acerca do tema, é questão que vem sendo discutida e combatida na jurisprudência há mais de uma década com 
base, inicialmente, em princípios gerais de direito, e atualmente também com base nos julgados reiterados dos Tribunais.

As denúncias criminais contra quem se vale de trabalho escravo são muito importantes para coibir a mantença dessa prática nefanda, mas a legislação penal - por razões já explicitadas - não se volta contra esse tipo de delinquência e de delinquente. O protagonismo da Justiça do Trabalho nesse aspecto é indiscutível, máxime com a criação de "listas sujas" para incluir o nome de pessoas condenadas em sede do judiciário trabalhista por trabalho escravo. A atuação do Ministério Público Federal e dos Auditores do Ministério do Trabalho e Emprego tem trazido à baila toda essa questão com muito mais ênfase que a Justiça Federal, e seus métodos de execução são outros: se o digesto penal possui o poder de encarceramento do patrão delinquente, o sistema jurídico trabalhista propicia sua condenação, em dinheiro, por danos morais causados à coletividade, de sorte a embaraçar o delinquente quanto à sua gana por lucro desenfreado.

Decerto o poder em retirar do convívio social quem assim age é punição exemplar, que serve de modelo à sociedade e acaba por preveni-la contra quem escraviza seu semelhante. A dogmática penal, contudo, segue a legalidade em sentido estrito e nem sempre se amolda a outras formas tão aviltantes de trabalho como aquele exercido em condições análogas à de escravo - uma prova disso é a hermenêutica que pode ser feita em torno do trabalho degradante, que se assemelha muito ao delito em comento, mas nem sempre é abarcado por ele. Por tudo isso, e também para que a Justiça do Trabalho se mantenha em constante atualização contra novas formas de trabalho escravo, deverá ela adotar também formas de punição exemplar.

O conceito de punição exemplar (ou punitive damages) está atrelado ao conceito de dano moral. Este deve ser o instrumento que permite buscar a reparação integral por alguma lesão sofrida. O dano moral deve ter em conta, sempre, a dignidade da pessoa humana, e não questões aferíveis apenas sob o ponto de vista subjetivo, qual seja, dor, sofrimento ou tormentos da alma. Quando se toma por base a violação à dignidade da pessoa humana como objeto da tutela do dano moral, a sua reparação não pode ficar adstrita à verificação das condições econômicas ou o nível social da vítima, porque a dignidade alheia não é mensurável por critérios econômicos para que haja reparação integral (MORAES, 2003, p. 331-332). 
Não se trata de mera punição ou retribuição, nos dizeres de Maria Celina Bodin de Moraes: a verificação dos critérios de condição econômica do agressor e gravidade da culpa dizem respeito à lesão moral, que é a causa de um possível efeito, qual seja, o dano moral. Somente em se considerando as condições pessoais da vítima e a dimensão do dano (sua repercussão social e sua gravidade) é que se poderá estabelecer uma tutela de reparação integral à vítima e de punição ao causador do dano, o que é de todo compatível com a noção de dano moral como lesão à dignidade humana (2003, p. 332).

Em verdade, é necessário salientar que existe a necessidade da lesão, mas o efeito (dano moral) poderá ou não ocorrer no plano fático; basta, pois, que a lesão praticada pelo autor seja considerada lesiva à dignidade da pessoa humana (SCRAMIM, 2014, p. 199-200), como sói ocorrer nos casos em que alguém é submetido a trabalho escravo em quaisquer de suas modalidades adotadas pelo sistema justrabalhista.

Os punitive damages não se confundem com a indenização por dano moral, que deve ou deveria - ter função de reparação integral pela lesão sofrida. O sistema, que teve suas origens na Inglaterra mas se popularizou nos Estados Unidos da América, sustenta que a responsabilidade civil não deve apenas reparar a lesão sofrida, mas também prevenir a reincidência do ilícito, a fim de demonstrar ao infrator e à sociedade em geral que a prática do ilícito não compensa. Essa é a razão, aliás, para que sejam estabelecidos valores altíssimos a serem pagos pela prática de algum ilícito, valores esses que são muito superiores à reparação do ilícito (CUNHA, 2014, p. 547). Nos países de cultura ocidental, como é o caso do Brasil, ressalta-se a ótica socializante dessas punições, que devem ser reprimidas quando se demonstram socialmente graves (LEVY, 2011, p. 192), como é o caso do trabalho em condições análogas à de escravo. No Brasil, tal condenação seria destinada a algum fundo social sob o epíteto de dano moral coletivo.

Nessa toada, a condenação em punitive damages como instrumento de prevenção de danos pode ter associação com a responsabilidade pressuposta, sobre a qual Giselda Maria Novaes Hironaka bem explora. O título de seu livro, "Responsabilidade Pressuposta", disso não deixa dúvidas: é preciso que o sistema de reparação civil, mormente por danos morais coletivos, tenha mais a noção de proteção aos direitos humanos fundamentais do que, necessariamente, o ressarcimento ou a punição e, por isso, a responsabilidade civil também poderia ser adotada de forma preventiva. Conforme a autora, 
certamente têm razão os juristas da contemporaneidade que reclamam por uma construção legislativa que garantisse mesmo, não caso a caso, mas sob uma formatação mais genérica, essa hipótese de imputação legal de responsabilidade não individualizada, quer dizer, coletivizada, tendo em vista que tal providência retiraria a variação jurisprudencial que ainda existe e que pode conter, pelos seus traços de imutabilidade, resquícios de injustiça e ausência de equidade. Atualmente, a atenção de todo o sistema de responsabilidade civil se volta, assim como se disse, para as vítimas, não apenas porque os danos são mais graves, mas também, e sobretudo, porque em quase todos os casos o responsável tinha a possibilidade ou a obrigação de se garantir e garantir a segurança dos demais, aos quais acaba por vitimar (2005, p. 144).

Graves lesões a direitos fundamentais da pessoa humana e ao aviltamento da dignidade da pessoa humana (mesmo se interpretada de maneira medíocre) revelam-se como atos que merecem a punição exemplar, a fim de reprimir a delinquência patronal. Sem o rigor formalista da dogmática penal, o sistema justrabalhista possui maior agilidade e, muito provavelmente, também maior eficiência para impor penalidades gravosas a quem se vale de trabalho em condições análogas à de escravo para acumular capital. Saliente-se, ademais, que a tutela trabalhista não impede a existência da criminal, e vice-versa (exceto quando a pessoa acusada de reduzir pessoa a condição análoga à de escravo é absolvida por inocência no juízo criminal, não bastando a absolvição por falta de provas).

A condenação no juízo trabalhista se dá a título de dano moral coletivo, que

corresponde à lesão injusta e intolerável a interesses ou direitos titularizados pela coletividade (considerada em seu todo ou em qualquer de suas expressões - grupos, classes ou categorias de pessoas), os quais possuem natureza extrapatrimonial, refletindo valores e bens fundamentais para a sociedade (MEDEIROS NETO, 2007, p. 137).

Quando a dignidade humana é aviltada de forma tão evidente quanto na questão do trabalho escravo, é evidente que há, de fato - e não apenas por retórica - uma lesão coletiva, que engendra dano a toda a sociedade. Mesmo o sistema de produção capitalista poderá ser tido como vítima dessa prática, já que o produtor que se vale de mão-de-obra remunerada em preço justo e cumpre com todas as suas obrigações trabalhistas poderá sofrer concorrência desleal em face de outro produtor que se vale de trabalho escravo. O custo dessa produção, 
que é excessivamente barateada pela afronta à dignidade de diversos obreiros e por eventuais crimes cometidos, poderá ser ofertado a preço tão baixo que não permita ao empregador honesto competir com o empregador delinquente. A toda evidência, o dano ora aventado não se restringe aos produtores, e nem mesmo a seus subordinados, mas a toda uma coletividade vale dizer, à sociedade. $\mathrm{O}$ dano moral coletivo resta, pois, claramente evidenciado na situação ora narrada.

O processo trabalhista, que prima pela busca da verdade real - tal como o criminal, é certo - possui agilidade muito maior que o procedimento penal, e é também acompanhado de menos formalidades que aquelas existentes na seara de aplicação das penas. A prevenção e repressão ao trabalho escravo no Brasil já é protagonizada pelo Ministério Público do Trabalho, por meio do ajuizamento de Ação Civil Pública contra a delinquência patronal. Já que se admite ao Parquet requerer até mesmo direitos individuais homogêneos (LOTTO, 2015, p. 92), torna-se muito mais efetiva a tutela trazida pelo arcabouço do sistema jurídico trabalhista, vez que poderá haver cumulação de pedidos. A condenação do empregador delinquente à punição exemplar, em quantia revertida a algum fundo social específico, na defesa de interesses coletivos, é uma dessas formas de tutela.

Ademais, o Ministério Público do Trabalho poderá requerer na mesma ação o pleito de dano moral individualmente sofrido por todas as vítimas do trabalho escravo, a título de defesa de direitos individuais homogêneos. Tal solução, em acordo com o diálogo de fontes (regras, princípios gerais de direito e/ou jurisprudência) existentes no ordenamento jurídico brasileiro é, na presente proposta, a forma mais eficaz e rápida de proteger a dignidade humana da pessoa escravizada, além de servir de exemplo a todo e qualquer empregador delinquente que o ilícito não compensa de maneira alguma.

\section{Considerações Finais}

Em conformidade com as reflexões trazidas pelo presente estudo, há que se explorar bem o conceito de delinquência patronal, até mesmo como forma de frisar, jurídica e socialmente, a ilicitude do trabalho em condições análogas à de escravo. Não há razão para que se alegue, conforme explanado ao longo do texto, que a sua definição no artigo 149 do Código Penal seja imprecisa, vaga ou extremamente subjetiva. Ao menos por tudo quanto foi 
exposto no presente texto, a caracterização de determinado trabalho como escravo pode ser objetivamente aferida.

O bem jurídico-penal tutelado pelo digesto penal é tanto a liberdade quanto a dignidade da pessoa do trabalhador; no entanto, parcela considerável da doutrina e também da jurisprudência dos Tribunais (STF, TRF e TST) exige, para a caracterização do trabalho escravo, a restrição da liberdade de ir e vir, de forma a reduzir muito consideravelmente o alcance do conceito de trabalho escravo que, repise-se, já se encontra disposto em lei. Para essa parcela, que parece comungar de Projetos de Lei apresentados na Câmara dos Deputados e no Senado Federal acerca do tema, ainda que se contrarie a norma penal em sua literalidade, a restrição da liberdade é que configura crime quando, pela natureza das condições degradantes de trabalho ou pelas jornadas exaustivas a liberdade pessoa resta comprometida.

O conceito, embora advindo do direito penal, não existe em um mundo jurídico apartado de outras searas: o sistema jurídico trabalhista, por exemplo, baseia-se no próprio conceito presente no citado artigo 149 para balizar suas decisões acerca da existência ou inexistência de caracterização de trabalho escravo. A discussão na seara trabalhista também se dá em relação à restrição da liberdade de ir e vir como premissa para caracterização do trabalho escravo, mas paulatinamente o Ministério Público do Trabalho tem fundamentado tal caracterização também no desrespeito absoluto e grosseiro da dignidade da pessoa humana do trabalhador.

Por certo não há conceitos jurídicos - salvo raríssimas exceções - que sejam matematicamente precisos. $\mathrm{O}$ aviltamento da dignidade da pessoa humana pode ser visto das mais diversas formas e sob diferentes ângulos, é verdade, mas o que sucede no trabalho escravo é algo que consegue tornar claro, até mesmo para a sensibilidade mediana de quem não possui formação jurídica, que se trata de algo aviltante. Exemplos podem ser citados: cortar com facão, em poda, 10 (dez) toneladas de cana de açúcar por dia, não ter água potável para beber, contar com instalações precárias (feita com lonas, por exemplo), enfim, não são de fato - coerção direta do capitalista contra a vítima do trabalho escravo, mas se enquadram perfeitamente na noção presente no artigo 149 do Código Penal.

O sistema jurídico trabalhista pode e deve dar respostas à sociedade quanto à tutela de quem se submete ao trabalho escravo: para além de a interpretação justrabalhista ser mais flexível que a penal, em se tratando de crimes há uma questão principiológica: na dúvida, 
favorece-se o réu, que será o latifundiário. No direito do trabalho, o princípio existente é o de que, na dúvida, favorece-se a parte hipossuficiente da relação, ou seja, o trabalhador (escravizado, in casu).

As Ações Civis Públicas movidas com o protagonismo notável do Ministério Público do Trabalho têm conferido autoridade à Justiça Trabalhista para falar sobre trabalho escravo, autoridade esta que é jurídica e socialmente reconhecida como superior à da Justiça Federal, que deveria buscar a condenação criminal de quem se vale do trabalho escravo para acumular capital e, em assim agindo, atenta até mesmo contra a livre iniciativa e o valor social do trabalho.

Esse diálogo de fontes entre direito penal, constitucional e trabalhista tem permitido a tutela de direitos fundamentais da pessoa do trabalhador em diversas frentes. Muitas vezes não se consegue privar a liberdade de quem privou a liberdade de muitos: é difícil a condenação penal do empregador delinquente, mesmo porque, consoante exposto, o sistema penal parece conseguir selecionar seus alvos com bastante precisão, e a classe dos latifundiários não se encontra nesse alvo. Há quem defenda seus interesses no Congresso Nacional.

O processo trabalhista, que é muito mais ágil e detém menos formalidade que o da seara criminal, permite a responsabilização da delinquência patronal com a condenação em danos morais coletivos, decorrentes da grave lesão praticada contra valores reconhecidos pela sociedade como relevantes, sendo possível também cumular o pedido indenizatório a todas as vítimas, de forma a reparar integralmente o dano sofrido. A responsabilidade civil, porém, costuma atuar sempre ex post facto, ou seja, após a prática de uma lesão. Esse não é um bom encaminhamento: a responsabilidade também deve ser preventiva, para demonstrar que atos ilícitos não compensam. Daí porque se defendeu a punição exemplar (punitive damages) para questões dessa natureza, porque coíbem talvez de maneira mais eficiente a possível escravização de trabalhadores.

Um aspecto a ser discutido oportunamente é a possibilidade de expropriação dos locais em que se encontre trabalho escravo, conforme determina o artigo 243 da Constituição Federal, em redação dada pela Emenda Constitucional 81, de 05 de junho de 2014 (CONSTITUIÇÃO, 2016). Essa questão - ainda muito recente no cenário jurídico - já começa a sofrer embates políticos para que o conceito de trabalho escravo seja extremamente 
reduzido, o que caracteriza retrocesso social. Definitivamente, tais alterações não são permitidas pelo sistema jurídico constitucional. Todavia, uma dúvida remanesce: a expropriação poderá ser dada mediante sentença trabalhista ou somente após a condenação criminal do empregador delinquente? Esta é, seguramente, uma discussão que se tornará emblemática e atingirá o mundo jurídico em grande escala, constituindo-se em mais um capítulo da luta contra o trabalho escravo no Brasil.

\section{Referências bibliográficas}

ABRAMO, Laís; MACHADO, Luiz. O combate ao trabalho forçado: um desafio global. in: NOCCHI, Andrea Saint Pastous; VELLOSO, Gabriel Napoleão; FAVA, Marcos Neves (coords.). Trabalho escravo contemporâneo: o desafio de superar a negação. 2. ed. São Paulo: LTr, 2011. p. 60-75.

ALONSO OLEA, Manuel. Derecho del Trabajo. Atualiz. Maria Emilia Casas Baamonde. 26. ed. Madrid: Civitas, 2009.

AZEVEDO NETO, Platon Teixeira. O trabalho decente como um direto humano. São Paulo: LTr, 2015.

BENJAMIN, Walter. O capitalismo como religião. Trad. Nélio Schneider. São Paulo: Boitempo, 2013.

BRASIL. Decreto-Lei 2.848, de 7 de dezembro de 1940. [online]. Disponível via WWW em: $<$ http://www.planalto.gov.br/ccivil_03/decreto-lei/Del2848compilado.htm>. Acesso em 08 jan. 2016.

BRITO FILHO, José Cláudio Monteiro de. Trabalho decente: análise jurídica da exploração do trabalho - trabalho escravo e outras formas de trabalho indigno. 3. ed. São Paulo: LTr, 2013.

Trabalho escravo: algumas questões importantes para sua compensação.

Revista Fórum Trabalhista, Belo Horizonte, v.3, n.13, p.45-58. jul./ago. 2014a.

Trabalho escravo: caracterização jurídica. São Paulo: LTr, 2014 b.

BUSSE, Matthias; BRAUN, Sebastian. Valoración empírica de los efectos del trabajo forzoso en el comercio y las inversiones. Revista Internacional del Trabajo, Ginebra, v.122, n.1, p.5580. 2003.

CÂMARA dos Deputados. Projeto de Lei da Câmara 3.842, de 09 de maio de 2012. [online]. Disponível via WWW em: <http://www2.camara.leg.br/proposicoesWeb/ fichadetramitacao?idProposicao=544185>. Acesso em 03 jan. 2016.

CASTEL, Robert. As metamorfoses da questão social: uma crônica do salário. Trad. Iraci D. Poleti. 6. ed. Petrópolis: Vozes, 1998.

CONSTITUIÇÃO da República Federativa do Brasil de 1988. [online]. Disponível via WWW em: <http://www.planalto.gov.br/ccivil_03/Constituicao/Constituicao.htm>. Acesso em 20 jan. 2016.

CUNHA, Eduardo Maia Tenório da. Responsabilidade civil trabalhista e a doutrina dos punitive damages na Justiça do Trabalho brasileira. Revista LTr, São Paulo, v.78, n.5, p.542553. mai. 2014. 
DELGADO, Maurício Godinho. Curso de Direito do Trabalho. 14. ed. São Paulo: LTr, 2015. EWALD, François. L'État Providence. Paris: Bernard Grasset, 1986.

FERRAJOLI, Luigi. Por uma teoria dos direitos e dos bens fundamentais. Trad. Alexandre Salim, Alfredo Copetti Neto, Daniela Cademartori, Hermes Zaneti Júnior e Sérgio Cademartori. Porto Alegre: Livraria do Advogado, 2011.

FILGUEIRAS, Vítor Araújo; ALVES, Jeane Sales. Trabalho análogo ao escravo no Brasil: regulação em disputa e recentes resgates no Estado da Bahia. Revista do Tribunal Superior do Trabalho, Rio de Janeiro, v.80, n.1, p.303-328. jan./mar. 2014.

FOUCAULT, Michel. A arqueologia do saber. Trad. Luiz Felipe Baeta Neves. 7. ed. Rio de Janeiro: Forense Universitária, 2008.

2005.

Microfísica do Poder. Trad. Roberto Machado. 21. ed. Rio de Janeiro: Graal,

FRANCO FILHO, Georgenor de Sousa. A emenda constitucional n. 81/2014 e o trabalho forçado no Brasil. Revista do Tribunal Regional do Trabalho da $8^{a}$ Região, Belém, v.47, n.93, p.45-56. jul./dez. 2014.

GARCIA, Gustavo Filipe Barbosa. Trabalho escravo, forçado e degradante: trabalho análogo à condição de escravo e expropriação da propriedade. Justiça do Trabalho, Porto Alegre, v.29, n.344, p.92-99. ago. 2012.

HADDAD, Carlos Henrique Borlido. Aspectos penais do trabalho escravo. Revista de Informação Legislativa, Brasília, v.50, n.197, p.51-64. jan./mar. 2013.

HIRONAKA, Giselda Maria Fernandes Novaes. Responsabilidade Pressuposta. Belo Horizonte: Del Rey, 2005.

LEVY, Daniel de Almeida. Uma visão cultural dos punitive damages. Revista de Direito Privado, São Paulo, v.12, n.45, p.165-216. jan./mar. 2011.

LORENZETTI, Ricardo Luís. Teoria da decisão judicial: fundamentos de direito. 2. ed. Trad. Bruno Miragem. São Paulo: Revista dos Tribunais, 2010.

LOTTO, Luciana Aparecida. Ação civil pública trabalhista contra o trabalho escravo no Brasil. 2. ed. São Paulo: LTr, 2015.

MACHADO, Sidnei. Trabalho escravo e trabalho livre no Brasil: alguns paradoxos históricos do direito do trabalho. Revista da Faculdade de Direito da Universidade Federal do Paraná, Curitiba, v.38, p.151-158. 2003.

MARTINS, José de Souza. Uma sociologia da vida cotidiana. São Paulo: Contexto, 2014.

MATTJE, Emerson Tyrone. Expressões contemporâneas de trabalho escravo: sua repressão penal no Brasil. Santa Cruz do Sul: Edunisc, 2006.

MEDEIROS NETO, Xisto Tiago de. Dano Moral Coletivo. 2. ed. São Paulo: LTr, 2007.

MENDES, Gilmar Ferreira; BRANCO, Paulo Gustavo Gonet. Curso de Direito Constitucional. 9 ed. São Paulo: Saraiva, 2014.

MIRAGLIA, Lívia Mendes Moreira. Trabalho escravo contemporâneo: conceituação à luz do princípio da dignidade da pessoa humana. 2. ed. São Paulo: LTr, 2015.

MORAES, Maria Celina Bodin de. Danos à pessoa humana: uma leitura civil-constitucional dos danos morais. Rio de Janeiro: Renovar, 2003.

PLANT, Roger. Trabajo forzoso, migración y trata de personas. Educación Obrera, Ginebra, n.129, p.66-74. 2002.

POULANTZAS, Nicos. A lei. in: NAVES, Márcio B.; BARROS, J. M. de Aguiar. Crítica do Direito. São Paulo: Livraria Editora Ciências Humanas, 1980. p. 63-82.

RAMOS FILHO, Wilson. Neo-escravismo no Brasil contemporâneo: crime e castigo. Revista da Faculdade de Direito da Universidade Federal do Paraná, Curitiba, n.48, p.87-106. 2008. 
RASSAM, Anne-Yasmine. Contemporary forms of slavery and evolution of the prohibition of slavery and the slave trade under customary international law. Virginia Journal of International Law, Virginia, v.39, n.2, p.303-352. 1999.

ROMAGNOLI, Umberto. La libertad sindical, hoy. Revista de Derecho Social, v.4, n. 14, p. 9-23, abr./jun. 2001.

SALADINI, Ana Paula Sefrin. Trabalho e imigração. São Paulo: LTr, 2012.

SANTOS, Boaventura de Sousa. O direito dos oprimidos. São Paulo: Cortez, 2014.

SCRAMIM, Umberto Cassiano Garcia. O dano moral e sua problemática: quantificação, função punitiva e os punitive damages. Revista de Direito Privado, São Paulo, v. 15, n. 60, p.195-214. out./dez. 2014.

SENADO Federal. Projeto de Lei do Senado 432, de 18 de outubro de 2013. [online]. Disponível via WWW em: <http://www25.senado.leg.br/web/atividade/materias//materia/114895>. Acesso em 10 jan. 2016.

SERVAIS, Jean-Michel. Le droit international social contre la pauvreté: un cadre de réflexion. Revue de la Faculté de Droit de l'Université de Liège, Liège, n.3, p.289-319. 2010.

ZAFFARONI, Eugenio Raúl. Em busca das penas perdidas: a perda de legitimidade do sistema penal. Trad. Vânia Romano Pedrosa e Amir Lopes da Conceição. Rio de Janeiro: Revan, 1991. 